\title{
The hidden Mediterranean diet: wild vegetables traditionally gathered and consumed in the Gargano area, Apulia, SE Italy
}

\author{
Nello Biscotti ${ }^{1}$, Andrea Pieroni* \\ ${ }^{1}$ Corso Carmine 84, 71018 Vico del Gargano (Foggia), Italy \\ ${ }^{2}$ University of Gastronomic Sciences, Piazza Vittorio Emanuele 9, 12060 Bra/Pollenzo, Italy
}

\begin{abstract}
Despite the extensive bio-scientific literature concerning the Mediterranean diet, which emerged in the last three decades, systematic ethnography-centered investigations on a crucial portion of this food system, linked to the traditional consumption of non-cultivated vegetables, are still largely lacking in many areas of the Mediterranean Basin.

In this research, an ethnobotanical field study focusing on wild vegetables traditionally gathered and consumed locally, was conducted in a few centers and villages located in the Gargano area, northern Apulia, SE Italy, by interviewing twentyfive elderly informants. The folk culinary uses of seventy-nine botanical taxa of wild vascular plants, belonging to nineteen families, were recorded, thus showing a remarkable resilience of traditional environmental knowledge (TEK) related to wild food plants. In particular, approximately one-fourth of the recorded wild vegetables are still very commonly gathered and consumed nowadays, while ten taxa have never been reported in previous ethnobotanical studies conducted in Southern Italy. These findings demonstrate the crucial cultural role played by folk cuisines in preserving TEK, despite significant socio-economic changes that have affected the study area during the past four decades.
\end{abstract}

Keywords: ethnobotany; wild food plants; Apulia; Mediterranean diet; Italy

\section{Introduction}

The Mediterranean diet - the theorization of which was proposed for the first time in the cross-cultural epidemiological "Seven countries study" by the American nutritionist Ancel Benjamin Keys [1,2] - has been defined as a diet "characterized by abundant plant foods, fresh fruit as the typical daily dessert, olive oil as the principal source of fat, dairy products (principally cheese and yogurt), and fish and poultry consumed in low to moderate amounts, zero to four eggs consumed weekly, red meat consumed in low amounts, and wine consumed in low to moderate amounts, normally with meals" [3].

Moreover, this diet has been ascribed to "food patterns typical of Crete, much of the rest of Greece, and southern Italy in the early 1960s, where adult life expectancy was among the highest in the world and rates of coronary heart disease, certain cancers, and other diet-related chronic diseases were among the lowest" [3].

Within this context, the consumption of wild vegetables in Southern Europe, however, still represents a kind of "hidden" part of the Mediterranean diet, despite the large scientific

*Corresponding author. Email: a.pieroni@netcologne.de

Handling Editor: Łukasz Łuczaj literature pointing out the benefits of this dietary pattern and the fact that this diet has been recently recognized as a UNESCO Intangible Cultural Heritage of Humanity [4], officially ascribed to a few circum-Mediterranean countries: Italy, Spain, Portugal, Morocco, Greece, Cyprus, and Croatia.

Wild vegetables of the Mediterranean diet have been at the center of a series of phytochemical and phytopharmacological studies in recent years that have demonstrated their role in counteracting metabolic diseases and as remarkable anti-oxidants [5-10]; moreover, wild vegetables are nowadays also the focus of many new trends of contemporary European cuisine, which stress the importance of the health benefits of local foods and expressions of terroirs/"sense of place" [11].

Despite the fact that these plants have represented for centuries and millennia the folk daily foods in the Mediterranean and the Near East, particularly during the winter and spring months, in-depth ethnography-based ethnobotanical studies published in the international literature and specifically focusing on the identification of traditionally gathered wild vegetables, as well as on the detailed documentation of their folk culinary uses, are still relatively scarce for the Mediterranean Basin, if we exclude some areas of Spain, inland southern Italy and Sicily, the Western Aegean part of Turkey, and Dalmatia [12-30].

The global scientific community should maybe consider the urgency of collecting information about these neglected 
foods from the remaining traditional knowledge holders in order to record in detail the plant-based part of the folk daily diet of the rural classes of the Mediterranean region.

In this study, we contribute to this challenging task by conducting an ethnobotanical survey on the wild vegetables still gathered and consumed in the Gargano area, SE Italy. This area is in fact considered crucial for understanding the true nature of vegetable-based diets in Italy, as it is located within a region (Apulia) where the local folk cuisine is wellknown for its remarkable use of both neglected (cultivated) and wild plants.

The specific aims of this study were:

(i) to record the local names and specific traditional culinary uses of wild vegetables, which are still gathered in the selected area;

(ii) to compare the collected ethnobotanical data with the south Italian and South European ethnobotanical literature, in order to point out possible new or unusual plant culinary uses; and

(iii) to compare the collected data with an ethnographycentered ethnobotanical investigation conducted in the same area in 1961, in order to observe the continuity and change of folk culinary uses of wild vegetables.

\section{Material and methods}

\section{Selected site}

The field study site consisted of the Gargano area, located within the Foggia Province, northern Apulia region, SE Italy (Fig. 1). Gargano is mainly represented by a hilly promontory that extends into the Adriatic Sea; since 1991, it has been entirely included within Gargano National Park, which has an area of $1180 \mathrm{~km}^{2}$, of which half is devoted to agro-pastoral activities and approximately one-fifth is covered by forests.

This promontory is characterized by a particular Mediterranean climate, largely influenced by north winds, which bring humidity and significant rainfall (up to $1300 \mathrm{~mm}$ per year). This peculiarity, together with the mainly karstic geology of the promontory, has enabled the development of a remarkable variety of habitats: karst plateaus with steep cliffs falling into the sea, coastal lagoons, salty steppes, maquis shrublands, hills, and woody valleys. The costal and sub-coastal areas are covered by prickly junipers (Juniperus oxycedrus L.), as well as Aleppo pines (Pinus halepensis Mill.), diverse oak species (Quercus spp.), hop hornbeams (Ostrya carpinifolia Scop.), and Italian maples [Acer opalus subsp. obtusatum (Waldst. \& Kit. ex Willd.) Gams]. In the mountainous areas, which are wooded up to approximately $830 \mathrm{~m}$ a.s.l., Turkey and Italian oaks (Quercus cerris L., Q. frainetto Ten.), chestnut trees (Castanea sativa L.), European hornbeams (Carpinus betulus L.), beeches (Fagus sylvatica L.), yews (Taxus baccata L.), and field maples (Acer campestre L.) dominate. Finally, in the most humid canyons the dominant species are bay laurels (Laurus nobilis L.), wych elms (Ulmus glabra Huds.), and large-leaved lime trees (Tilia platyphyllos Scop.).

The flora is extremely rich and includes ca. 2100 plant species [31], with a number of important endemic taxa (such as Asperula garganica Huter, Porta \& Rigo ex Ehrend. \& Krendl, Campanula garganica Ten.), rare species of the Italian flora [i.e., Cistus clusii Dunal, Clinopodium serpyllifolium subsp. fruticosum (L.) Bräuchler], and Balkan elements as well [i.e., Scabiosa crenata subsp. dallaportae (Heldr. ex Boiss.) Hayek, Inula verbascifolia (Willd.) Haussk.].

The agronomic landscape is characterized by orchards of citrus species, almond (Fig. 2), carob, and olive trees. Until a few decades ago, the traditional economic model of the area was characterized by a mixture of agricultural and pastoralist (sheep and cattle breeding) activities. While the development of tourism has changed this in the last few decades, the area still hosts a number of small-scale farmers.

The main town of Foggia is home to a daily fruit and vegetable market, where, during the winter and the spring months, a dozen stalls - a few of them managed unofficially by elderly famers/sellers - offer several wild vegetables; the same happens on street corners of this city as well as in a number of minor centers of the province.

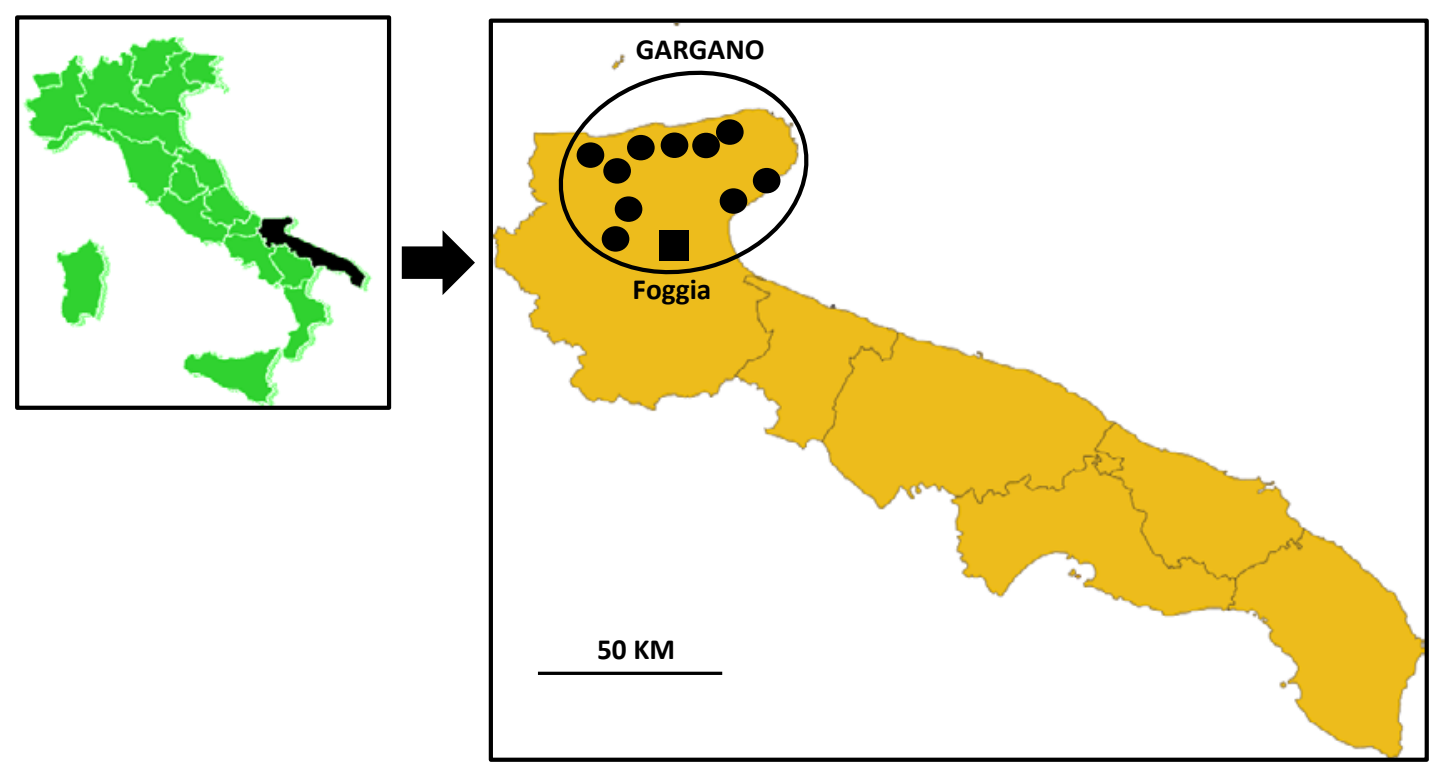

Fig. 1 The study site and visited centers. 


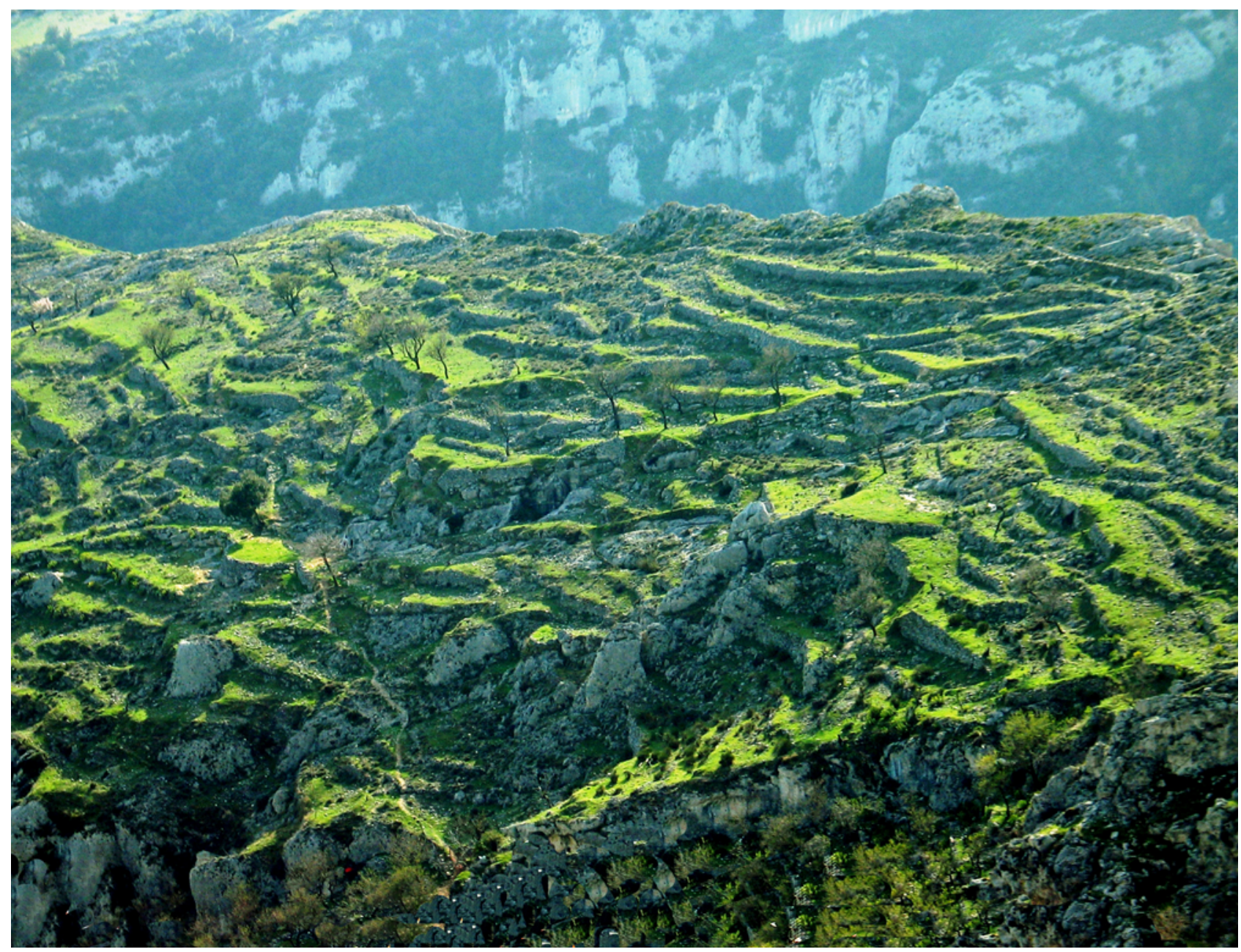

Fig. 2 Almond tree orchards in the Gargano, one of the most favorite spots for gathering wild vegetables in the winter and spring months.

In Foggia, the foraging of wild vegetables was part of the "specialized" skills retained by a specific section of the local city population, called Terrazzani. These "marginal" peoples were historically, and are still partially nowadays, involved in the gathering/foraging activities of wild food plants, and also mushrooms, snails, frogs, and (mainly illegally hunted) wild birds and small mammals, such as wild rabbits, hedgehogs, and badgers, for food. In the past, Terrazzani were used to gather and sell these items to the local agrarian bourgeoisie; nowadays, the few remaining Terrazzani sell their foraged foods on the street corners of Foggia (Fig. 3, Fig. 4).

The major part of the local population of the Gargano area is employed nowadays in small-scale agricultural activities (particularly related to olive tree and vegetable farming) and especially in the touristic industry, (the Gargano area hosting nowadays approximately $80 \%$ of all tourists visiting Apulia). The area is still heavily affected by migration of the youngest generations to northern Italy and Germany, motivated by the search for better job opportunities.

The local population of the Gargano area speaks a variety of dialects, which belong to the Daunian branch of the southern Italian languages.

\section{Field study}

In the years 2011-2014, the following centers and villages of the Gargano area were visited: Foggia, San Severo, Manfredonia, Cagnano Varano, Scanzano, San Nicandro, Vico del Gargano, Apricena, Lesina, Carpino, Lucera, and Mattinata. Twenty-five elderly informants between the ages of 39 and 80 years (but primarily 65-75 years) were selected among those locals who could be identified as traditional knowledge holders (normally Terrazzani and elderly smallscale farmers and shepherds), employing snowball-sampling techniques. These individuals then were interviewed after prior informed consent was verbally obtained. The focus of the interviews, which were conducted in both standard Italian and the Daunian dialect, was the folk knowledge (name and use) of the wild vegetables they still gather during the winter and spring months, i.e., the focus of the study was on current (and not past) wild vegetables perceptions and uses.

The Code of Ethics of the International Society of Ethnobiology [32] was strictly followed.

The wild plant species mentioned by the informants were collected, when available, and identified by the first author according to Flora d'Italia [33], and stored at the Herbarium 


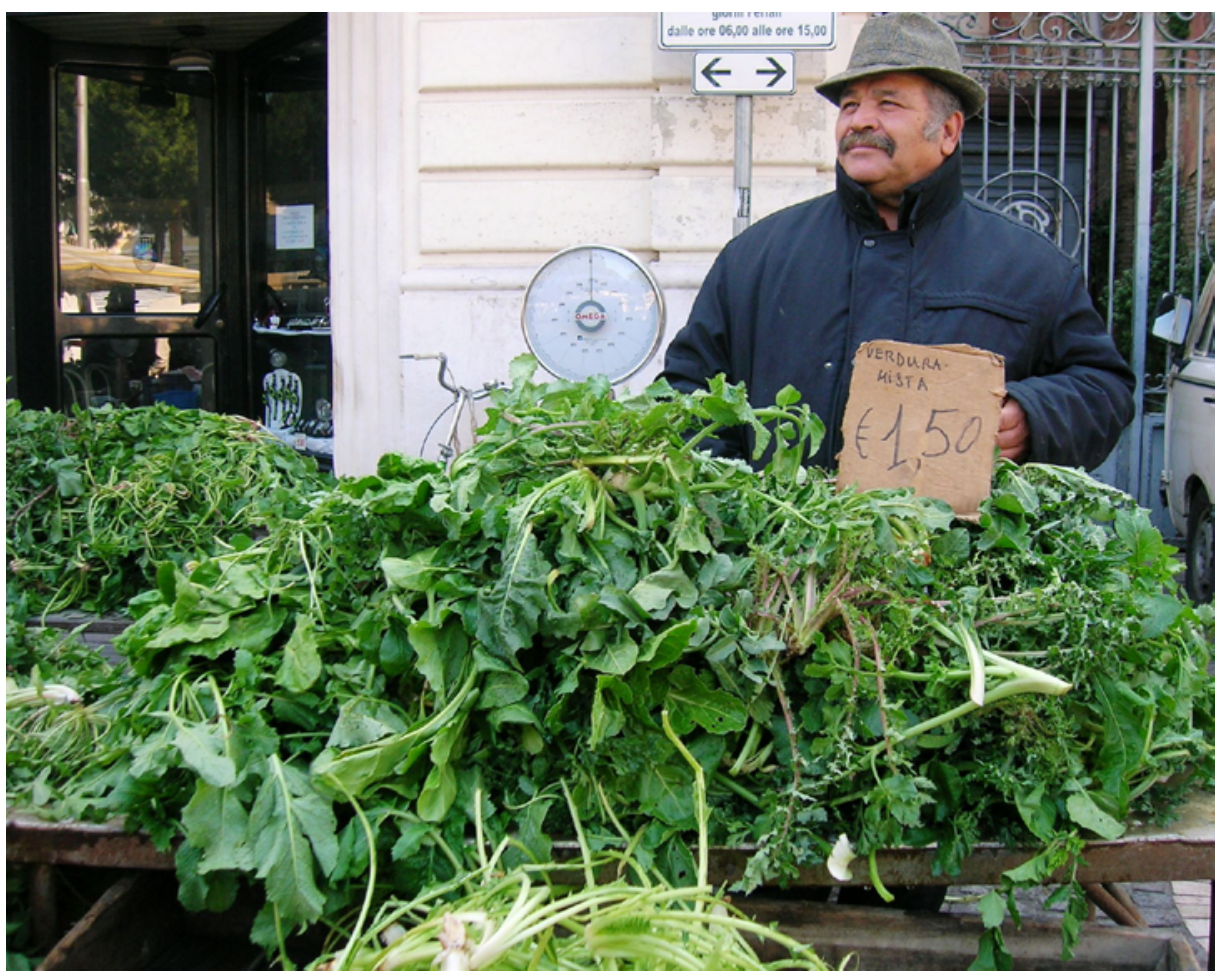

Fig. 3 One of the last Terrazzani and most knowledgeable informants in the present study, while selling wild vegetables in the city center of Foggia: Antonio Marzano (nickname: U' Cinese, "The Chinese").

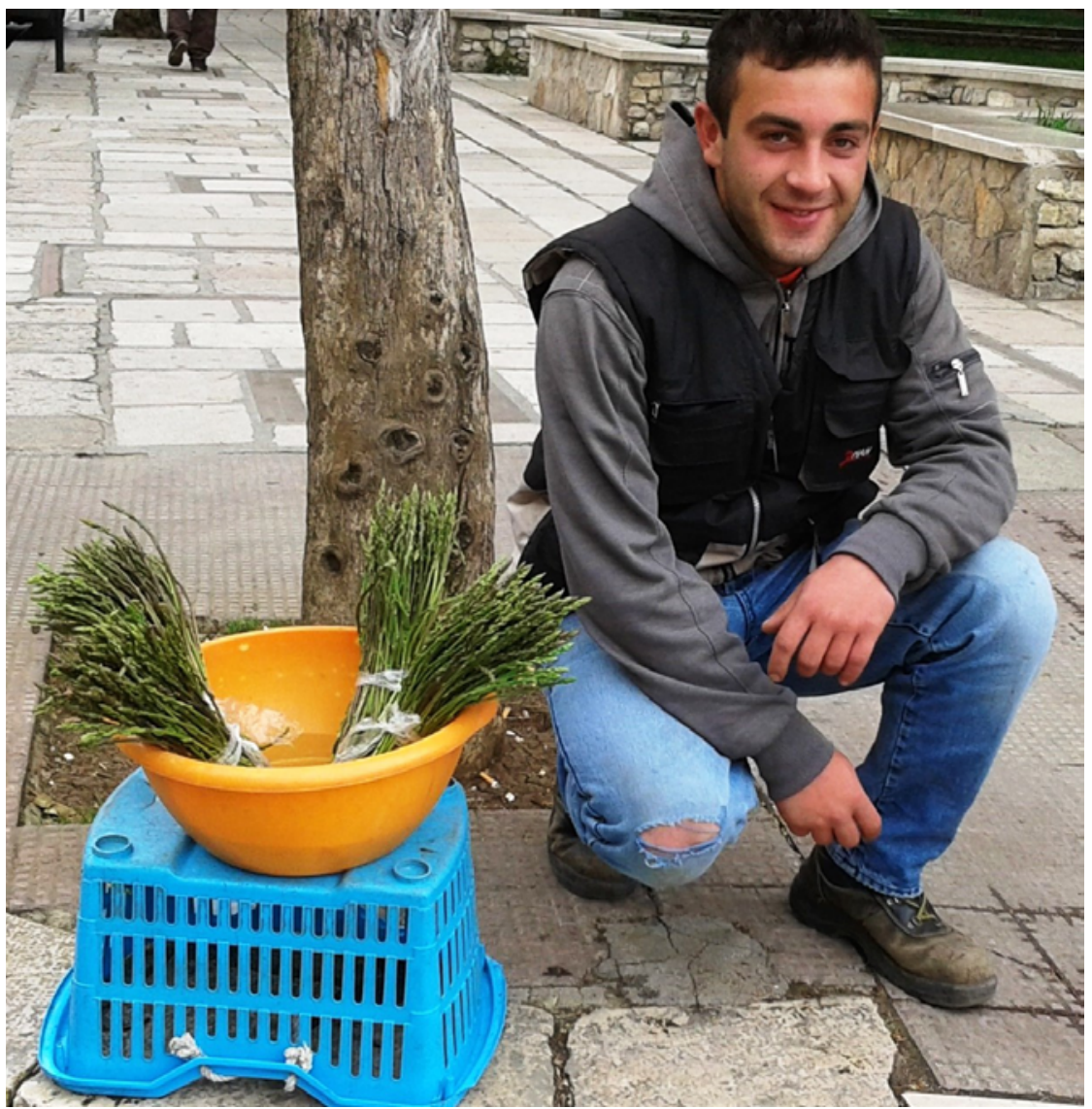

Fig. 4 Young man selling wild asparagus (Asparagus acutifolius) shoots. 
Anconitanum (Marche Polytechnical University, Ancona, Italy). Nomenclature follows the standards set by The Plant List database [34], while plant family assignments follow the current Angiosperm Phylogeny Group designations [35].

\section{Data analysis}

We compared the data gathered during the field study with the following sources: the entire Italian ethnobotanical database (last updated in 2004) [36], the south-Italian ethnobotanical surveys that have been published in international journals and have (also) considered wild plants traditionally used in local cuisines [21-26,37-41], national ethnobotanical literature sources and popular references in which sound ethnobotanical observations were reported [42-54], as well as wild food plant-centered ethnobotanical studies conducted in Southern Europe and published in international journals [12-20,27-30].

Finally, we compared the collected data with an ethnography-centered ethnobotanical investigation conducted in the same area in 1961 [55].

\section{Results}

Tab. 1 shows the recorded folk names and culinary uses of wild vegetables.

Sixty-seven folk taxa corresponding to seventy-nine botanical taxa of wild vascular plants, belonging to nineteen families, were found to represent the current local wild vegetable-based culinary heritage. The discrepancy between the two numbers is due, as already well documented for wild vegetables in other South-European areas [21], to the phenomenon known in ethnobiological linguistics as under-differentiation (locals naming diverse, mainly "similar", botanical taxa with one folk name only).

If we compare this data with the south Italian ethnobotanical literature of the last two decades [28-36], this is probably one the richest heritages in terms of the diversity of wild food plants still gathered and consumed ever recorded in mainland Italy.

Most of the reported wild vegetables are represented by "greens", i.e., wild leafy vegetables, that mainly belong to the families of Asteraceae (30 botanical taxa) and Brassicaceae (10 botanical taxa), as is the case in most Mediterranean wild food plant-based folk cuisines, and, for what regards the popularity of wild food Brassicaceae, particularly in Sicily [25].

The prevalence of these two families may be explained by both the appreciation of the bitter and pungent tastes of the gathered botanical species belonging to these families, and the fact that elderly locals tend to link these tastes to the belief that these ingredients are important elements of a "healthy" diet, sometimes even ascribing them clear medicinal properties, as described in other studies focusing on the South-Italian paradigm of wild plant-based food-medicines and folk functional foods $[21,56,57]$.

Beyond leafy vegetables, there are, however, a few exceptions: two vines (Dioscorea communis, Smilax aspera) and one shrub (Pistacia terebinthus), of which Gargano locals use the young, tender shoots; three wild leek and garlic species
(Allium ampeloprasum, A. commutatum, and A. pendulinum), of which (also) the bulbs are consumed; and tassel hyacinth (Leopoldia comosa), whose bulbs may represent the most iconic foraged ingredient of Apulian folk cuisine, according to which they are fried with eggs to make a kind of bitter omelette (Fig. 5).

The most common culinary use of the recorded wild greens is boiling them in mixtures, locally known as fogghja mmisché ("mixed leaves"), and simply consuming them dressed only with olive oil and vinegar or lemon juice.

A variation of this mixture is the folk culinary preparation pancotto, in which old bread is boiled in water together with the wild greens, and, at the end, the entire preparation is dressed with abundant olive oil.

With some of the reported taxa (notably Diplotaxis tenuifolia, Foeniculum vulgare, Sinapis spp., Raphanus raphanistrum) a typical local festivity dish is prepared: home-made pasta (maccheroni or orecchiette) is "married" with the wild vegetables, either raw or blanched, which are then fried together in a pan with olive oil and garlic.

In rare cases, specific wild greens become the main ingredients of special dishes, such as eel-based (Tripolium pannonicum, Taraxacum obovatum) or lake fish-based (Sonchus maritimus) soups, as well as side dishes of roasted lamb meat during Easter festivities (Scolymus hispanicus).

A small number of taxa are simply consumed raw, as a snack, with bread, or, more often, in salads (Reichardia picroides, Diplotaxis tenuifolia, Sanguisorba minor, and even the light toxic shoots of Dioscorea communis); for example, a peculiar traditional salad preparation consists of mixing the young aerial parts of Cerinthe major with oranges (Fig. 6). It is also worth mentioning the culinary tradition of roasting wild garlic and leek bulbs (particularly Allium ampeloprasum, but also A. commutatum and A. pendulinum which are very rarely used elsewhere in Italy), and especially young shoots of Asphodeline spp.

Moreover, we compared the collected data with an indepth folkloric investigation conducted in the same area in 1961 by the ethnographer and cleric Cleto Corrain [55]. The wild vegetables which were mentioned as widely used 55 years ago were: Asparagus acutifolius, Beta vulgaris, Capparis spp., Cichorium intybus, Foeniculum vulgare, Hirschfeldia incana, Portulaca oleracea, Reichardia picroides, Sonchus spp., Sinapis spp., and Taraxacum officinale. These species represented and still represent the core of the wild vegetable-based folk cuisine of the Gargano area. The collection of wild Ruta ssp. (probably as seasoning) and Sedum acre, which were mentioned by the Reverend Corrain, seem to have been abandoned in the study area.

\section{Discussion}

Although traditional small-scale agro-pastoral activities increasingly mixed in the last few decades with the development of tourism, and the lifestyle of peasants during the past several centuries no longer exists in the study area, the use of wild vegetables in folk cuisines is still very much alive.

The reasons for this permanence can be found in the resilience of a plant-based traditional cuisine, which retains 
Tab. 1 Wild vegetables gathered and consumed in the study area.

\begin{tabular}{|c|c|c|c|c|c|}
\hline $\begin{array}{l}\text { Botanical taxon/taxa, family, } \\
\text { and voucher specimen code(s) }\end{array}$ & Local name(s) & Used parts & $\begin{array}{l}\text { Traditional culinary } \\
\text { use(s) }\end{array}$ & $\begin{array}{l}\text { Frequency of } \\
\text { quotation }\end{array}$ & $\begin{array}{l}\text { Previous records } \\
\text { in the south Italian } \\
\text { ethnobotanical } \\
\text { literature }\end{array}$ \\
\hline $\begin{array}{l}\text { Allium ampeloprasum L., } \\
\text { Amaryllidaceae, } 6430\end{array}$ & $\begin{array}{l}\text { Riddìddé, Cipoddé } \\
\text { carràré }\end{array}$ & $\begin{array}{l}\text { Bulb, stem, young } \\
\text { leaves }\end{array}$ & $\begin{array}{l}\text { Raw in mixed salads; } \\
\text { roasted and dressed } \\
\text { with olive oil }\end{array}$ & C & yes \\
\hline $\begin{array}{l}\text { Allium commutatum Guss., } \\
\text { Amaryllidaceae, } 9331\end{array}$ & Agghié selvaggé & $\begin{array}{l}\text { Bulb, stem, young } \\
\text { leaves }\end{array}$ & $\begin{array}{l}\text { Raw in mixed salads; } \\
\text { roasted and dressed } \\
\text { with olive oil }\end{array}$ & $\mathrm{C}$ & yes \\
\hline $\begin{array}{l}\text { Allium pendulinum Ten., } \\
\text { Amaryllidaceae, } 16384\end{array}$ & Liscìna & $\begin{array}{l}\text { Bulb, stem, young } \\
\text { leaves }\end{array}$ & $\begin{array}{l}\text { Raw in mixed salads; } \\
\text { roasted and dressed } \\
\text { with olive oil }\end{array}$ & $\mathrm{R}$ & yes \\
\hline $\begin{array}{l}\text { Amaranthus retroflexus L., } \\
\text { Amaranthaceae, } 13354\end{array}$ & Agghjìtòné & Young leaves & Boiled, then on pasta & $\mathrm{C}$ & yes \\
\hline Ammi majus L., Apiaceae, 14790 & Spróvlé & Aerial parts & $\begin{array}{l}\text { Boiled then on pasta, } \\
\text { dressing with "pecorino" } \\
\text { cheese and olive oil }\end{array}$ & $\mathrm{R}$ & yes \\
\hline $\begin{array}{l}\text { Apium nodiflorum (L.) Lag., } \\
\text { Apiaceae, } 13466\end{array}$ & Accio selvaggé & Aerial parts & $\begin{array}{l}\text { Raw in salads; seasoning } \\
\text { soups }\end{array}$ & $\mathrm{C}$ & yes \\
\hline $\begin{array}{l}\text { Asparagus acutifolius L., } \\
\text { Asparagaceae, } 17188\end{array}$ & Spar’jé & Young shoots & $\begin{array}{l}\text { Boiled and dressed with } \\
\text { olive oil; fried with eggs; } \\
\text { boiled, then on pasta; } \\
\text { boiled and pickled in } \\
\text { olive oil }\end{array}$ & VC & yes \\
\hline $\begin{array}{l}\text { Asphodeline lutea (L.) Rchb. and A. } \\
\text { liburnica (Scop.) Rchb., } \\
\text { Xanthorrhoeaceae, } 10115 \text { and } 9504\end{array}$ & $\begin{array}{l}\text { Calcacavallo, Coda di } \\
\text { Cavallo }\end{array}$ & Shoots & $\begin{array}{l}\text { Roasted (shoots have to } \\
\text { be previously peeled) }\end{array}$ & C & yes \\
\hline $\begin{array}{l}\text { Beta vulgaris L., Amaranthaceae, } \\
10593\end{array}$ & Ghjéeta & Whorls & $\begin{array}{l}\text { Boiled, on pasta or in } \\
\text { boiled mixtures }\end{array}$ & VC & yes \\
\hline Borago officinalis L., Boraginaceae & $\begin{array}{l}\text { Burraccèllé, } \\
\text { Burraccèddé, Vurràine, } \\
\text { Murraine, Vorràine }\end{array}$ & Aerial parts & $\begin{array}{l}\text { Boiled and dressed with } \\
\text { olive oil; in soups with } \\
\text { pumpkin and fava beans }\end{array}$ & VC & yes \\
\hline $\begin{array}{l}\text { Bunias erucago L., Brassicaceae, } \\
25978\end{array}$ & $\begin{array}{l}\text { Pisciacane, } \\
\text { Cagnapurcedd, Làss'n' }\end{array}$ & Whorls & Boiled in mixtures & $\mathrm{C}$ & yes \\
\hline $\begin{array}{l}\text { Calepina irregularis (Asso) Thell., } \\
\text { Brassicaceae, } 16354\end{array}$ & Insalata selvaggia & Whorls & $\begin{array}{l}\text { Raw in mixed salads; } \\
\text { boiled in mixtures }\end{array}$ & $\mathrm{R}$ & \\
\hline $\begin{array}{l}\text { Capparis spinosa L., Capparaceae, } \\
12266\end{array}$ & Chjapparìni & $\begin{array}{l}\text { Flower buds, } \\
\text { fruits }\end{array}$ & $\begin{array}{l}\text { In salads; boiled and } \\
\text { pickled; seasoning }\end{array}$ & VC & yes \\
\hline $\begin{array}{l}\text { Capsella bursa-pastoris (L.) Medik., } \\
\text { Brassicaceae, } 13286\end{array}$ & Insalata selvaggia & Whorls & $\begin{array}{l}\text { Boiled on pasta or in } \\
\text { mixtures }\end{array}$ & $\mathrm{R}$ & yes \\
\hline $\begin{array}{l}\text { Carlina corymbosa } \mathrm{L} \text {. and } C \text {. } \\
\text { vulgaris } \mathrm{L} \text {., Asteraceae, } 19591\end{array}$ & Cardùcci & Young leaves & Boiled in mixtures & $\mathrm{R}$ & yes \\
\hline $\begin{array}{l}\text { Centaurea sicula L. and C. } \\
\text { solstitialis L., Asteraceae, } 19337 \\
\text { and } 19344\end{array}$ & $\begin{array}{l}\text { Occhio ruggio, } \\
\text { Ciarucciolo }\end{array}$ & Young leaves & Boiled in mixtures & $\mathrm{R}$ & yes \\
\hline $\begin{array}{l}\text { Cerinthe major L., Boraginaceae, } \\
25388\end{array}$ & Sucamèlé & $\begin{array}{l}\text { Young leaves and } \\
\text { flowers }\end{array}$ & $\begin{array}{l}\text { Raw in salads with } \\
\text { orange slices, dressing } \\
\text { with olive oil and } \\
\text { vinegar }\end{array}$ & $\mathrm{R}$ & \\
\hline $\begin{array}{l}\text { Chondrilla juncea L., Asteraceae, } \\
24304\end{array}$ & J'nstròddé & Young shoots & $\begin{array}{l}\text { Raw, as a snack with } \\
\text { bread }\end{array}$ & $\mathrm{R}$ & yes \\
\hline $\begin{array}{l}\text { Cichorium intybus L., Asteraceae, } \\
20684\end{array}$ & C'còrji, Cicurieddé & Whorls, shoots & $\begin{array}{l}\text { Blanched and fried on } \\
\text { pasta, or with eggs; in } \\
\text { boiled mixtures }\end{array}$ & VC & yes \\
\hline $\begin{array}{l}\text { Clematis vitalba L., Ranunculaceae, } \\
19431\end{array}$ & $\begin{array}{l}\text { Focomorto, Vutàcchjé, } \\
\text { Vitécchjé }\end{array}$ & Shoots & $\begin{array}{l}\text { Omelettes; boiled in } \\
\text { mixtures }\end{array}$ & $\mathrm{R}$ & yes \\
\hline $\begin{array}{l}\text { Crepis vesicaria L. subp. } \\
\text { taraxacifolia (Thuill.) Thellung, } \\
\text { Asteraceae }\end{array}$ & Cicuriuné & Young leaves & Boiled in mixtures & C & yes \\
\hline
\end{tabular}


Tab. 1 (continued)

\begin{tabular}{|c|c|c|c|c|c|}
\hline $\begin{array}{l}\text { Botanical taxon/taxa, family, } \\
\text { and voucher specimen code(s) }\end{array}$ & Local name(s) & Used parts & $\begin{array}{l}\text { Traditional culinary } \\
\text { use(s) }\end{array}$ & $\begin{array}{c}\text { Frequency of } \\
\text { quotation }\end{array}$ & $\begin{array}{c}\text { Previous records } \\
\text { in the south Italian } \\
\text { ethnobotanical } \\
\text { literature }\end{array}$ \\
\hline $\begin{array}{l}\text { Crithmum maritimum L., Apiaceae, } \\
16865\end{array}$ & Finùcchjé di mare & $\begin{array}{l}\text { Young leaves, } \\
\text { shoots }\end{array}$ & $\begin{array}{l}\text { Boiled and dressed with } \\
\text { vinegar (or lemon juice) } \\
\text { and olive oil }\end{array}$ & $\mathrm{R}$ & yes \\
\hline Cynara cardunculus L., Asteraceae & Cardùné, Scarciof 'lé & Stems, whorls & $\begin{array}{l}\text { Boiled and then deep } \\
\text { fried }\end{array}$ & $\mathrm{R}$ & yes \\
\hline $\begin{array}{l}\text { Diplotaxis tenuifolia (L.) DC., } \\
\text { Brassicaceae, } 15816\end{array}$ & Ruchetta & $\begin{array}{l}\text { Young aerial } \\
\text { parts }\end{array}$ & $\begin{array}{l}\text { Raw with bread; in } \\
\text { salads with tomatoes, } \\
\text { olive oil and vinegar; } \\
\text { on pasta }\end{array}$ & $\mathrm{VC}$ & yes \\
\hline $\begin{array}{l}\text { Dioscorea communis (L.) Caddick } \\
\text { \& Wilkin, Dioscoreaceae, } 17101\end{array}$ & Ràfané & $\begin{array}{l}\text { Leaves, young } \\
\text { stems }\end{array}$ & $\begin{array}{l}\text { Raw as a snack, with } \\
\text { bread; boiled and } \\
\text { dressed with vinegar } \\
\text { and olive oil; pickled }\end{array}$ & $\mathrm{R}$ & yes \\
\hline $\begin{array}{l}\text { Dipsacum fullonum L., } \\
\text { Caprifoliaceae, } 11275\end{array}$ & Cicoriuné, Brùschié & Young leaves & Boiled in mixtures & $\mathrm{R}$ & \\
\hline $\begin{array}{l}\text { Foeniculum vulgare ssp. piperitum } \\
\text { (C. Presl.) Bég, Apiaceae, } \\
11506\end{array}$ & $\begin{array}{l}\text { Finucchjìddé, } \\
\text { Finucchjiàstré }\end{array}$ & $\begin{array}{l}\text { Young aerial } \\
\text { parts and fruits }\end{array}$ & $\begin{array}{l}\text { Boiled, then on pasta or } \\
\text { in mixed vegetables }\end{array}$ & $\mathrm{VC}$ & yes \\
\hline $\begin{array}{l}\text { Ferula communis L., Apiaceae, } \\
12554\end{array}$ & Frèula & Inflorescences & Deep fried & $\mathrm{R}$ & yes \\
\hline $\begin{array}{l}\text { Helminthotheca echioides (L.) } \\
\text { Holub. and Picris hieracioides } \\
\text { Sibth. \& Sim., Asteraceae, } 14488 \\
\text { and } 19873\end{array}$ & $\begin{array}{l}\text { Spurràiné, Raspalingua } \\
\text { Sfurràina, Spràiné }\end{array}$ & Whorls & Boiled in mixtures & $\mathrm{C}$ & yes \\
\hline $\begin{array}{l}\text { Hirschfeldia incana (L.) Lagr.-Foss., } \\
\text { Brassicaceae, } 16476\end{array}$ & Cimamarélla & $\begin{array}{l}\text { Whorls and } \\
\text { shoots }\end{array}$ & $\begin{array}{l}\text { Boiled, then on pasta or } \\
\text { in boiled mixtures }\end{array}$ & $\mathrm{C}$ & yes \\
\hline $\begin{array}{l}\text { Hyoseris radiata L., Asteraceae, } \\
11934\end{array}$ & Raspulìddé, Ruspigné & Inflorescences & $\begin{array}{l}\text { Raw as a snack, with } \\
\text { bread, or in salads }\end{array}$ & $\mathrm{R}$ & yes \\
\hline $\begin{array}{l}\text { Hypochaeris laevigata (L.) Ces. \& } \\
\text { al., Asteraceae }\end{array}$ & Ngìna & Young leaves & Boiled in mixtures & $\mathrm{R}$ & yes \\
\hline $\begin{array}{l}\text { Hypochaeris radicata L., } \\
\text { Asteraceae, } 23348\end{array}$ & Lingua di pecora & Young leaves & Boiled in mixtures & $\mathrm{R}$ & yes \\
\hline $\begin{array}{l}\text { Knautia integrifola (Honck. ex L.) } \\
\text { Bertol., Caprifoliaceae, } 13659\end{array}$ & Sghirbiùs' & Young leaves & Boiled in mixtures & $\mathrm{C}$ & \\
\hline $\begin{array}{l}\text { Lactuca serriola L., Asteraceae, } \\
11297\end{array}$ & Scaròla, Lattuquèddé & Whorls & Boiled in mixtures & $\mathrm{R}$ & yes \\
\hline $\begin{array}{l}\text { Lactuca viminea (L.) J. Presl \& C. } \\
\text { Presl., Asteraceae, } 14072\end{array}$ & Spaccaprété & Whorls & Boiled in mixtures & $\mathrm{C}$ & yes \\
\hline $\begin{array}{l}\text { Lasiospora hirsuta (Gouan) Cass., } \\
\text { Asteraceae, } 14540\end{array}$ & Panefarro & $\begin{array}{l}\text { Whorls, young } \\
\text { stems }\end{array}$ & $\begin{array}{l}\text { Raw as a snack, with } \\
\text { bread; in mixed } \\
\text { vegetables }\end{array}$ & $\mathrm{R}$ & yes \\
\hline $\begin{array}{l}\text { Leopoldia comosa (L.) Parl., } \\
\text { Asparagaceae, } 17120\end{array}$ & $\begin{array}{l}\text { Lampascione, } \\
\text { Cipudduzzé }\end{array}$ & Bulbs & $\begin{array}{l}\text { Roasted with lamb meat; } \\
\text { boiled, then in salads, } \\
\text { dressing with olive oil } \\
\text { and vinegar; boiled } \\
\text { and fried; pickled; in } \\
\text { omelettes }\end{array}$ & $\mathrm{VC}$ & yes \\
\hline $\begin{array}{l}\text { Nasturtium officinale R. Br., } \\
\text { Brassicaceae, } 15207\end{array}$ & Laurìddé, Ciotole & Aerial parts & $\begin{array}{l}\text { Raw in salad, dressing } \\
\text { with vinegar and olive } \\
\text { oil }\end{array}$ & $\mathrm{C}$ & yes \\
\hline $\begin{array}{l}\text { Ornithogalum pyramidale L., } \\
\text { Asparagaceae, } 9621\end{array}$ & Lampascione bianco & Bulbs & $\begin{array}{l}\text { Roasted; boiled and } \\
\text { pickled, consumed with } \\
\text { goat meat }\end{array}$ & $\mathrm{R}$ & Yes (O. umbellatum L.) \\
\hline $\begin{array}{l}\text { Papaver rhoeas L., Papaveraceae, } \\
19916\end{array}$ & Papagna & Whorls & Boiled in mixtures & $\mathrm{C}$ & yes \\
\hline
\end{tabular}


Tab. 1 (continued)

\begin{tabular}{|c|c|c|c|c|c|}
\hline $\begin{array}{l}\text { Botanical taxon/taxa, family, } \\
\text { and voucher specimen code(s) }\end{array}$ & Local name(s) & Used parts & $\begin{array}{l}\text { Traditional culinary } \\
\text { use(s) }\end{array}$ & $\begin{array}{l}\text { Frequency of } \\
\text { quotation }\end{array}$ & $\begin{array}{l}\text { Previous records } \\
\text { in the south Italian } \\
\text { ethnobotanical } \\
\text { literature }\end{array}$ \\
\hline $\begin{array}{l}\text { Pistacia terebinthus L., } \\
\text { Anacardiaceae, } 8935\end{array}$ & Legnamaro & Shoots & $\begin{array}{l}\text { Raw as a snack or in } \\
\text { boiled mixtures }\end{array}$ & $\mathrm{R}$ & \\
\hline $\begin{array}{l}\text { Portulaca oleracea L., } \\
\text { Portulacaceae }\end{array}$ & $\begin{array}{l}\text { Perchiàcchia, } \\
\text { Perchiàzzé } \\
\text { Purchàcchia }\end{array}$ & Aerial parts & $\begin{array}{l}\text { Raw in salads, } \\
\text { eventually mixed with } \\
\text { other vegetables }\end{array}$ & VC & yes \\
\hline $\begin{array}{l}\text { Raphanus raphanistrum L., } \\
\text { Brassicaceae, } 6064\end{array}$ & Pisciacàné, Lass'né & Whorls & $\begin{array}{l}\text { Boiled, then on pasta or } \\
\text { in mixtures }\end{array}$ & VC & yes \\
\hline $\begin{array}{l}\text { Reichardia picroides (L.) Roth., } \\
\text { Asteraceae, } 21571\end{array}$ & $\begin{array}{l}\text { Caccialepre, } \\
\text { Lattuqueddé }\end{array}$ & Whorls & Raw in salads & $\mathrm{C}$ & yes \\
\hline $\begin{array}{l}\text { Rubus ulmifolius Schott, Rosaceae, } \\
3883\end{array}$ & Rùvé, Ruvtàlé & $\begin{array}{l}\text { Young shoots and } \\
\text { leaves }\end{array}$ & Boiled in mixtures & $\mathrm{R}$ & yes \\
\hline $\begin{array}{l}\text { Ruscus aculeatus L., Asparagaceae, } \\
17080\end{array}$ & $\begin{array}{l}\text { Scupa pungicosa, } \\
\text { Scopa pungente, Scopa } \\
\text { fiscale, Scopa fruscale }\end{array}$ & Shoots & Boiled & $\mathrm{R}$ & yes \\
\hline $\begin{array}{l}\text { Salicornia emerici Duval-Jouve, } \\
\text { S. patula Duval-Jouve, and } \\
\text { Sarcocornia fruticosa (L.) A.J. Scott, } \\
\text { Amaranthaceae, } 25441 \\
26638 \text {, and } 12255\end{array}$ & $\begin{array}{l}\text { Savzòddé, Scorf'né, } \\
\text { Sauzariddé }\end{array}$ & Young stems & $\begin{array}{l}\text { Boiled and dressed with } \\
\text { olive oil, vinegar or } \\
\text { lemon juice; pickled }\end{array}$ & VC & yes \\
\hline $\begin{array}{l}\text { Salsola soda L., Amaranthaceae, } \\
10044\end{array}$ & Varvé di crèpé & Aerial parts & $\begin{array}{l}\text { Boiled and dressed with } \\
\text { vinegar and olive oil }\end{array}$ & $\mathrm{C}$ & yes \\
\hline $\begin{array}{l}\text { Sanguisorba minor Scop., Rosaceae, } \\
22152\end{array}$ & Pampanella & Young leaves & Raw in mixed salads & $\mathrm{C}$ & yes \\
\hline $\begin{array}{l}\text { Scolymus hispanicus L., Asteraceae, } \\
5632\end{array}$ & Cardùcci, Cardunciddé & Leaf stalks & $\begin{array}{l}\text { Cooked with eggs and } \\
\text { cheese }\end{array}$ & VC & yes \\
\hline $\begin{array}{l}\text { Scorzonera villosa Scop., } \\
\text { Asteraceae, } 16266\end{array}$ & Jèrvé di cràpé & $\begin{array}{l}\text { Whorls, young } \\
\text { stems }\end{array}$ & $\begin{array}{l}\text { Raw as a snack; boiled } \\
\text { in mixtures }\end{array}$ & $\mathrm{R}$ & \\
\hline $\begin{array}{l}\text { Scrophularia peregrina L., } \\
\text { Scrophulariaceae, } 2303\end{array}$ & Riddica selvaggia & $\begin{array}{l}\text { Whorls, young } \\
\text { stems }\end{array}$ & $\begin{array}{l}\text { Boiled, alone or in } \\
\text { mixtures }\end{array}$ & $\mathrm{R}$ & \\
\hline $\begin{array}{l}\text { Sinapis alba L. and S. arvensis L., } \\
\text { Brassicaceae, } 13263 \text { and } \\
4445\end{array}$ & $\begin{array}{l}\text { Sinapé selvaggia, } \\
\text { Cimarèddé dé chjiàné, } \\
\text { Fogghjè di chiàné }\end{array}$ & $\begin{array}{l}\text { Whorls, } \\
\text { young stems, } \\
\text { inflorescences }\end{array}$ & $\begin{array}{l}\text { Boiled and then on } \\
\text { pasta; or boiled in } \\
\text { mixtures }\end{array}$ & $\mathrm{VC}$ & yes \\
\hline $\begin{array}{l}\text { Sinapis pubescens L., Brassicaceae, } \\
16846\end{array}$ & $\begin{array}{l}\text { Paniconcato, Pane di } \\
\text { Gesù Cristo }\end{array}$ & $\begin{array}{l}\text { Young aerial } \\
\text { parts }\end{array}$ & Boiled in mixtures & $\mathrm{R}$ & yes \\
\hline $\begin{array}{l}\text { Smilax aspera L., Smilacaceae, } \\
19514\end{array}$ & Stracciagàtté & Shoots & $\begin{array}{l}\text { Raw as a snack; boiled; } \\
\text { pickled }\end{array}$ & $\mathrm{R}$ & yes \\
\hline Smyrnium olusatrum L., Apiaceae & Cannèla & $\begin{array}{l}\text { Young aerial } \\
\text { parts }\end{array}$ & $\begin{array}{l}\text { Raw in salad, with } \\
\text { vinegar and olive oil }\end{array}$ & $\mathrm{R}$ & yes \\
\hline $\begin{array}{l}\text { Sonchus asper (L.) Hill and S. } \\
\text { oleraceus L., Asteraceae, } 1647 \\
\text { and } 14785\end{array}$ & $\begin{array}{l}\text { Sévòné, Cecevedé, } \\
\text { Cascigno }\end{array}$ & $\begin{array}{l}\text { Young aerial } \\
\text { parts }\end{array}$ & $\begin{array}{l}\text { Boiled, alone or in } \\
\text { mixtures }\end{array}$ & $\mathrm{VC}$ & yes \\
\hline $\begin{array}{l}\text { Sonchus maritimus L., Asteraceae, } \\
12253\end{array}$ & Lattuquèddé & Whorls & In fish-based soups & $\mathrm{C}$ & \\
\hline $\begin{array}{l}\text { Stellaria media (L.) Vill., } \\
\text { Caryophyllaceae, } 18343\end{array}$ & Centògghjé & $\begin{array}{l}\text { Young aerial } \\
\text { parts }\end{array}$ & $\begin{array}{l}\text { Raw in salads; boiled in } \\
\text { mixtures }\end{array}$ & $\mathrm{R}$ & yes \\
\hline $\begin{array}{l}\text { Symphytum bulbosum K.F. } \\
\text { Schimp., Boraginaceae, } 23286\end{array}$ & Virrainóla & $\begin{array}{l}\text { Young aerial } \\
\text { parts }\end{array}$ & In boiled mixtures & $\mathrm{R}$ & \\
\hline $\begin{array}{l}\text { Taraxacum campylodes G.E. } \\
\text { Haglund and other Taraxacum } \\
\text { species [T. laevigatum (Willd.) } \\
\text { DC., T. megalorrhizon (Forssk.) } \\
\text { Hand.-Mazz., and T. obovatum } \\
\text { (Willd.) DC.], Asteraceae, } 9718\end{array}$ & Cicuriùné & Whorls & $\begin{array}{l}\text { Boiled in mixtures; } \\
\text { in eel-based soups }(T . \\
\text { obovatum })\end{array}$ & $\mathrm{C}$ & yes \\
\hline $\begin{array}{l}\text { Tragopogon porrifolius L., } \\
\text { Asteraceae, } 12086\end{array}$ & $\begin{array}{l}\text { Jèrvé de crépé, varve } \\
\text { de crépr, lenga di } \\
\text { pecura }\end{array}$ & $\begin{array}{l}\text { Leaves, young } \\
\text { stems }\end{array}$ & $\begin{array}{l}\text { Raw as a snack, or in } \\
\text { mixed salads }\end{array}$ & $\mathrm{C}$ & yes \\
\hline
\end{tabular}


Tab. 1 (continued)

\begin{tabular}{|c|c|c|c|c|c|}
\hline $\begin{array}{l}\text { Botanical taxon/taxa, family, } \\
\text { and voucher specimen code(s) }\end{array}$ & Local name(s) & Used parts & $\begin{array}{l}\text { Traditional culinary } \\
\text { use(s) }\end{array}$ & $\begin{array}{l}\text { Frequency of } \\
\text { quotation }\end{array}$ & $\begin{array}{l}\text { Previous records } \\
\text { in the south Italian } \\
\text { ethnobotanical } \\
\text { literature }\end{array}$ \\
\hline $\begin{array}{l}\text { Tripolium pannonicum (Jacq.) } \\
\text { Dobrocz., Asteraceae, } 9958\end{array}$ & Cet'la & Whorls, shoots & In lake fish-based soups & $\mathrm{C}$ & \\
\hline $\begin{array}{l}\text { Urospermum dalechampii (L.) } \\
\text { Scop.ex F.W. Schmidt, Asteraceae, } \\
17000\end{array}$ & $\begin{array}{l}\text { Cicuriuné riccio, } \\
\text { Cicuriuné gentile }\end{array}$ & Whorls & Boiled in mixtures & $\mathrm{C}$ & yes \\
\hline $\begin{array}{l}\text { Urospermum picroides (L.) Scop.ex } \\
\text { F.W. Schmidt, Asteraceae, } \\
\text { 25909 }\end{array}$ & $\begin{array}{l}\text { Iaddina grassa } \\
\text { Lattuquéddé, Fogghjé } \\
\text { di vacca }\end{array}$ & Whorls & Boiled in mixtures & VC & yes \\
\hline Urtica dioica L., Urticaceae, 13962 & Riddìca & Young leaves & Boiled in mixtures & $\mathrm{R}$ & yes \\
\hline
\end{tabular}

Frequency of citations: VC - very common: quoted by $40 \%(n=10)$ of the informants or more; C - common: quoted by $10-39 \%(n=$ $4-9)$ of the informants; $\mathrm{R}$ - rare: quoted by less than $10 \%(n=1-3)$ of the informants.

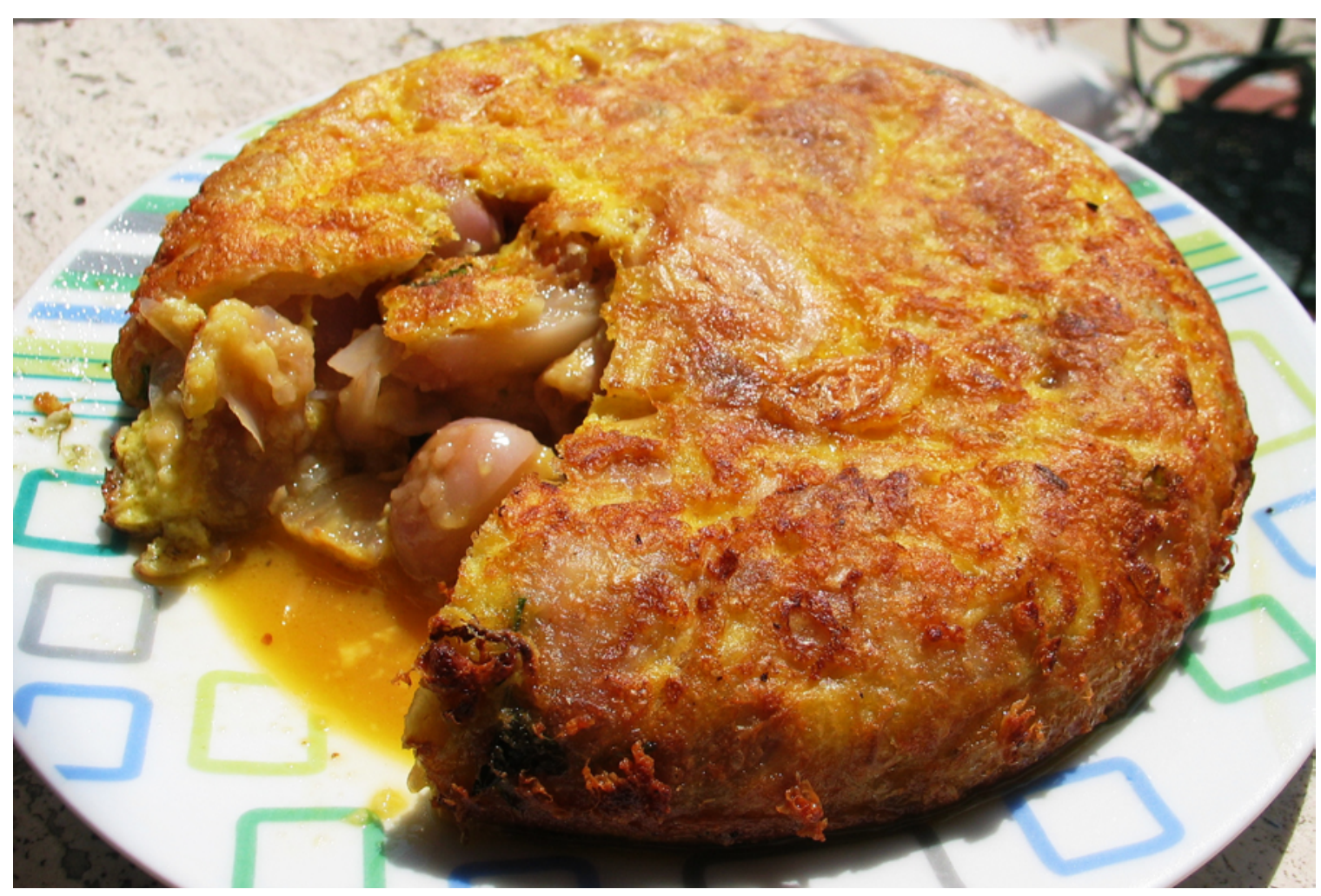

Fig. 5 The symbol of the Apulian wild vegetable-based cuisine: omelette made with the bulbs of wild Leopoldia comosa.

a crucial cultural value in northern Apulia and in SE Italy in general. The fact that approximately one-third of the recorded wild vegetables are still very frequently used in folk cuisine shows how the preservation of traditional environmental knowledge (TEK) related to wild food plants is actually enormously linked to the cultural meaning of the entire domain of traditional foods.

However, erosion of TEK related to wild vegetables is evident among the middle and youngest generations, and we question if this special environmental and culinary knowledge will be passed on to future generations of Gargano.
In the study area, local wild vegetables may have played an important role in the context of food security; the popularity of wild vegetables in the study area can also be traced in the historical socio-economic conditions of the rural classes in northern Apulia in the last few centuries. Gargano and the Foggia Province were (and partially still are) marked by large estates that occupy up to $80 \%$ of these territories, leaving until the recent past a multitude of "landless peasants" coping with dire economic conditions, which may have lead the them to shape their folk cuisine by using a significant diversity of wild food plants, instead of relying on cultivated vegetables. 


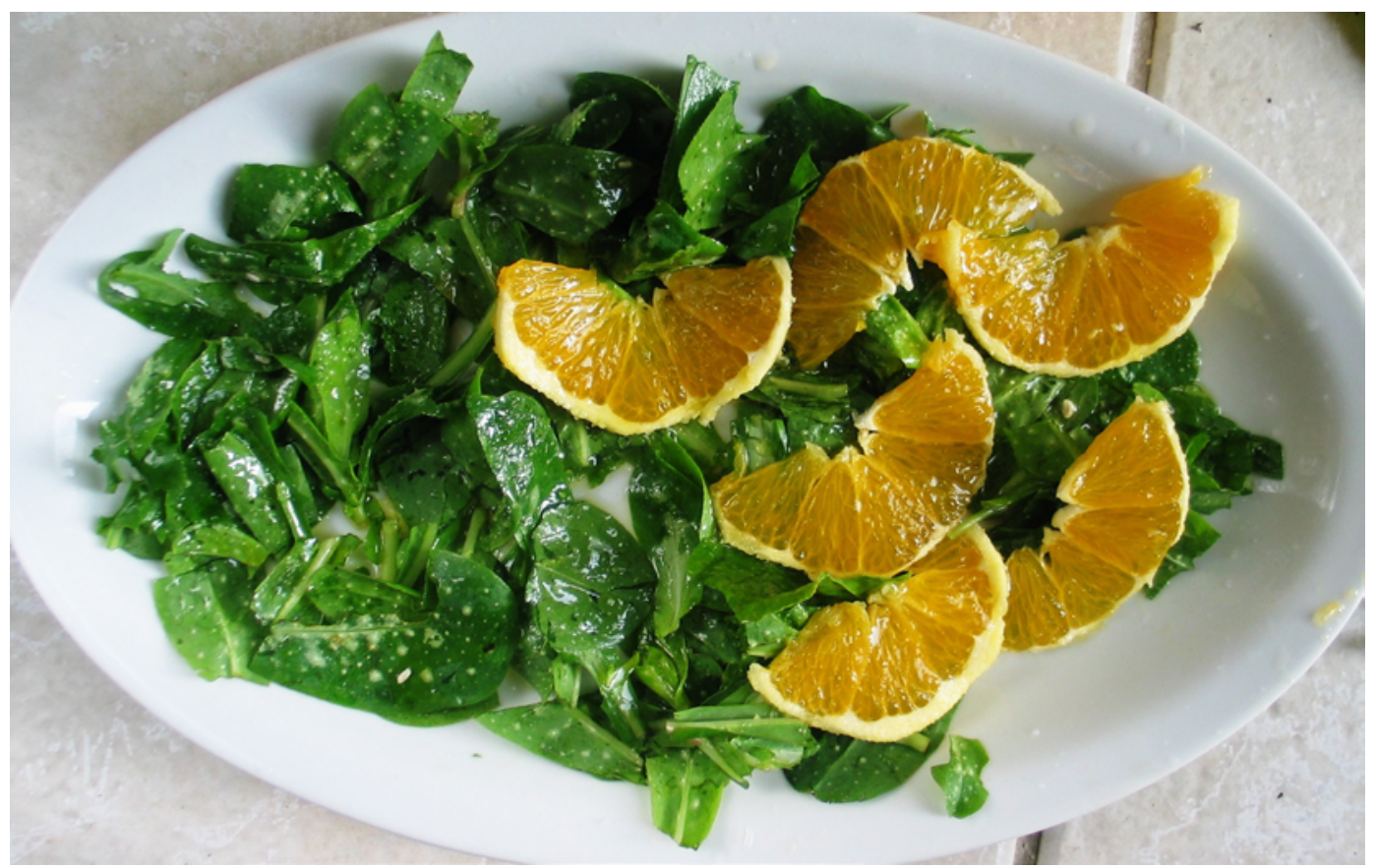

Fig. 6 A peculiar dish of the local cuisine: salad with young aerial parts of Cerinthe major and oranges.

Additionally, the high diversity of taxa found in the study area could also be linked to environmental diversity, i.e., variety of landscapes and habitats in Gargano; this is demonstrated by the high variability of recorded plant uses: the use of Picris echioides dominates in San Nicandro, Apricena, San Severo, Foggia, and Vieste; the use of Reichardia picroides, Smyrnium olusatrum, and Smilax aspera is prevalent in Vico del Gargano; the culinary utilization of Tripolium pannonicum is restricted to Cagnano Varano, Sonchus maritimus to Lesina, Crithmum maritimum to Vieste, and Sarcocornia and Salicornia spp. to Cagnano, San Nicandro, and Carpino.

Ten species were not previously recorded as edible items in the south Italian ethnobotany, thus showing that within southern Italy the Gargano area seems to have a special propensity for the survival of bio-cultural plant food refugia [58]. A few of these species are unknown or have been very rarely reported as part of the folk cuisines of South Europe: Allium pendulinum, Calepina irregularis, Scrophularia peregrina, Tripolium pannanicum, and Cerinthe major.

The unusual food uses of a few non-cultivated vegetables in the Gargano area, partially idiosyncratic with respect to southern Italian ethnobotany, can perhaps be explained as the result of not only the resilience of archaic uses which have disappeared elsewhere, but also the very complex historical vicissitudes that this area experienced over centuries. In particular, very diverse cultural influences and populations

\section{Acknowledgments}

Special thanks are due to all the study participants, who graciously agreed to share their folk plant knowledge; in particular, to Dora Paciello, 64 y.o. (Foggia); Giuseppe Milonia, 78 y.o. (Manfredonia); Antonia Del Priore, 74 y.o., Lucia Strizzi, 64 y.o., Francesca Del Luca, 69 y.o., Matteo Di Cataldo, 69 y.o. (Cagnano Varano); Maria Grazia Perrone, 70 y.o., Michele Merla, 78 y.o., Michele Scanzano, 59 y.o., Costantino Scanzano, 39 y.o., Cascavelli Nicolina, can be traced in Gargano: from the autochthonous, ancient Daunians, which probably originated from an Illyrian substrate, to successive Mediaeval Swabian, French, Turk, and Aragonese dominations.

The findings of this study indicate that the preservation of the bio-cultural intangible heritage of the local cuisine may need to go beyond the usual representations of the Mediterranean diet made by the media, which generally underline "only" common cultivated food plants, olive oil, home-made durum wheat pasta, and cheese.

Wild vegetables have represented and still represent a crucial, yet largely unknown, section of the Mediterranean diet, and the "dynamic" conservation of this food heritage requires strategies that carefully consider natural landscapes and resources as well as cultural customs, as wild plant folk knowledge systems are the result of a continuous interplay between these domains, which took place over centuries.

In other words, any bio-conservation strategy must consider the traditional culinary heritage of a territory, which may in turn foster strategies of sustainable gastronomy [59], promoting awareness for the need of both healthy environments and healthy diets.

In this way, the most uncommon wild vegetables noted in this study could represent a source of inspiration for both local restaurants and educational initiatives, as well as small-scale circuits of sustainable gathering and marketing of wild food plant ingredients.

65 y.o., Massaro Incoronata, 80 y.o. (San Nicandro); Santino Zaffarano, 74 y.o. (Vico del Gargano); Grimaldi Pietro, 39 y.o., Antonio Mastrone, 55 y.o., Giuseppe Mastrone, 60 y.o., Paolo Colangelo, 70 y.o., Michele de Lilla, 50 y.o., Marzaro Assunta, 69 y.o. (San Severo); Luigi Giuliani, 75 y.o. (Apricena); Angelo Circelli (Lucera); and Giuseppe Sansone, 73 y.o. (Mattinata); to the University of Gastronomic Sciences, for having funded the data analysis and the publication of the present work. 


\section{Authors' contributions}

The following declarations about authors' contributions to the research have been made: NB conducted the field study; AP and NB analyzed the data; AP drafted the first version of the manuscript, which was later revised by both authors.

\section{Competing interests}

No competing interests have been declared.

\section{References}

1. Keys A, Mienotti A, Karvonen MJ, Aravanis C, Blackburn H, Buzina $\mathrm{R}$, et al. The diet and 15-year death rate in the seven countries study. Am J Epidemiol. 1986;6:903-915.

2. Keys A. Mediterranean diet and public health: Personal reflections. Am J Clin Nutr. 1995;61:1321S-1323S.

3. Naska A, Trichopoulou A. Back to the future: the Mediterranean diet paradigm. Nutr Metab Cardiovasc Dis. 2014;24:216-219. http://dx.doi. org/10.1016/j.numecd.2013.11.007

4. UNESCO [Internet]. Mediterranean diet. 2013 [cited 2015 May 6]. Available from: http://www.unesco.org/culture/ich/index. php?lg=en\&pg=00011\&RL=00884

5. Fragopoulou E, Detopoulou P, Nomikos T, Pliakis E, Panagiotakos DB, Antonopoulou S. Mediterranean wild plants reduce postprandial platelet aggregation in patients with metabolic syndrome. Metabolism. 2012;61(3):325-334. http://dx.doi.org/10.1016/j.metabol.2011.07.006

6. Nomikos T, Detopoulou P, Fragopoulou E, Pliakis E, Antonopoulou S. Boiled wild artichoke reduces postprandial glycemic and insulinemic responses in normal subjects but has no effect on metabolic syndrome patients. Nutr Res. 2007;27(12):741-749. http://dx.doi.org/10.1016/j. nutres.2007.09.009

7. Heinrich M, Leonti M, Nebel S, Peschel W. "Local food - nutraceuticals". An example of a multidisciplinary research project on local knowledge. J Physiol Pharmacol. 2505;56(S1):5-22.

8. Conforti F, Marrelli M, Carmela C, Menichini F, Valentina P, Uzunov $\mathrm{D}$, et al. Bioactive phytonutrients (omega fatty acids, tocopherols, polyphenols), in vitro inhibition of nitric oxide production and free radical scavenging activity of non-cultivated Mediterranean vegetables. Food Chem. 2011;129(4):1413-1419. http://dx.doi.org/10.1016/j. foodchem.2011.05.085

9. Marrelli M, Loizzo MR, Nicoletti M, Menichini F, Conforti F. In vitro investigation of the potential health benefits of wild Mediterranean dietary plants as anti-obesity agents with $\alpha$-amylase and pancreatic lipase inhibitory activities. J Sci Food Agric. 2014;94(11):2217-2224. http://dx.doi.org/10.1002/jsfa.6544

10. Vasilopoulou E, Trichopoulou A. Green pies: the flavonoid rich Greek snack. Food Chem. 2011;126:855-858. http://dx.doi.org/10.1016/j. foodchem.2010.11.051

11. Łuczaj Ł, Pieroni A, Tardío J, Pardo-De-Santayana M, Sõukand R, Svanberg I, et al. Wild food plant use in 21st century Europe: the disappearance of old traditions and the search for new cuisines involving wild edibles. Acta Soc Bot Pol. 2012;81(4):359-370. http:// dx.doi.org/10.5586/asbp.2012.031

12. Łuczaj Ł, Zovkokoncic M, Milicevic T, Dolina K, Pandza M. Wild vegetable mixes sold in the markets of Dalmatia (southern Croatia). J Ethnobiol Ethnomed. 2013;9:2. http://dx.doi.org/10.1186/1746-4269-9-2

13. Łuczaj $Ł$, Dolina K. A hundred years of change in wild vegetable use in southern Herzegovina. J Ethnopharmacol. 2015;166:297-304. http:// dx.doi.org/10.1016/j.jep.2015.02.033

14. Dolina K, Łuczaj Ł. Wild food plants used on the Dubrovnik coast (south-eastern Croatia). Acta Soc Bot Pol. 2014;83(3):175-181. http:// dx.doi.org/10.5586/asbp.2014.029

15. Dogan Y. Traditionally used wild edible greens in the Aegean Region of Turkey. Acta Soc Bot Pol. 2012;81(4):329-341. http://dx.doi. org/10.5586/asbp.2012.037

16. Dogan Y, Ugulu I, Durkan, N. Wild edible plants sold in the local markets of Izmir, Turkey. Pak J Bot. 2013;45(S1):177-184.
17. Ertuğ, F. Wild edible plants of the Bodrum area (Muğla, Turkey). Turk J Bot. 2004;28:161-174.

18. Della A, Paraskeva-Hadjichambi D, Hadjichambis A. An ethnobotanical survey of wild edible plants of Paphos and Larnaca countryside of Cyprus. J Ethnobiol Ethnomed. 2006;2:34 http://dx.doi. org/10.1186/1746-4269-2-34

19. Hadjichambis A, Paraskeva-Hadjichambi D, Della A, Giusti ME, de Pasquale C, Lenzarini C, et al. Wild and semi-domesticated food plant consumption in seven circum-Mediterranean areas. Int J Food Sci Nutr. 2008;59(5):383-414. http://dx.doi.org/10.1080/09637480701566495

20. Leonti M, Nebel S, Rivera D, Heinrich M. Wild gathered food plants in the European Mediterranean: a comparative analysis. Econ Bot. 2006;60(2):130-142. http://dx.doi. org/10.1663/0013-0001(2006)60[130:WGFPIT]2.0.CO;2

21. Pieroni A, Nebel S, Quave CL, Münz H, Heinrich M. Ethnopharmacology of liakra, traditional weedy vegetables of the Arbëreshë of the Vulture area in southern Italy. J Ethnopharmacol. 2002;81:165-185. http://dx.doi.org/10.1016/S0378-8741(02)00052-1

22. Pieroni A, Nebel S, Santoro RF, Heinrich M. Food for two seasons: culinary uses of non-cultivated local vegetables and mushrooms in a south Italian village. Int J Food Sci Nutr. 2005;56:245-272. http:// dx.doi.org/10.1080/09637480500146564

23. Nebel S, Pieroni A, Heinrich M. Ta chorta: wild edible greens used in the Graecanic area in Calabria, southern Italy. Appetite. 2006;47:333342. http://dx.doi.org/10.1016/j.appet.2006.05.010

24. Guarrera PM, Salerno G, Caneva G. Food, flavouring and feed plant traditions in the Tyrrhenian sector of Basilicata, Italy. J Ethnobiol Ethnomed. 2006;2:37. http//dx.doi.org/10.1186/1746-4269-2-37

25. Lentini F, Venza F. Wild food plants of popular use in Sicily. J Ethnobiol Ethnomed. 2007;3:15. http://dx.doi.org/10.1186/1746-4269-3-15

26. Ghirardini MP, Carli M, del Vecchio N, Rovati A, Cova O, Valigi F, et al. The importance of a taste. A comparative study on wild food plant consumption in twenty-one local communities in Italy. J Ethnobiol Ethnomed. 2007;3:22. http://dx.doi.org/10.1186/1746-4269-3-22

27. Menendez-Baceta G, Aceituno-Mata L, Tardío J, Reyes-García V, Pardo-de-Santayana M. Wild edible plants traditionally gathered in Gorbeialdea (Biscay, Basque Country). Genet Resour Crop Evol. 2012;59(7):1329-1347. http://dx.doi.org/10.1007/s10722-011-9760-Z

28. Pardo-de-Santayana M, Tardío J, Blanco E, Carvalho AM, Lastra JJ, San Miguel E, et al. Traditional knowledge of wild edible plants used in the northwest of the Iberian Peninsula (Spain and Portugal): a comparative study. J Ethnobiol Ethnomed. 2007;3:27. http://dx.doi. org/10.1186/1746-4269-3-27

29. Pardo-De-Santayana M, Tardío J, Morales R. The gathering and consumption of wild edible plants in the Campoo (Cantabria, Spain). Int J Food Sci Nutr. 2005;56(7):529-542.

30. Tardío J, Pascual H, Morales R. Wild food plants traditionally used in the province of Madrid, central Spain. Econ Bot. 2005;59(2):122-136. http://dx.doi.org/10.1663/0013-0001(2005)059[0122:WFPTUI]2. $0 . \mathrm{CO} ; 2$

31. Biondi E, Casavecchia S, Biscotti N. Forest biodiversity of the Gargano Peninsula and a critical revision of the syntaxonomy of the mesophilous woods of southern Italy. Fitosociologia. 2008;45(2):93-127.

32. Society of Ethnobiology [Internet]. The ISE Code of Ethics. 2008 [cited 2015 May 8]; Available from: http://www.ethnobiology.net/ what-we-do/core-programs/ise-ethics-program/code-of-ethics/ code-in-english/

33. Pignatti S. Flora d'Italia. Bologna: Edagricole; 1997.

34. The Plant List - version 1.1 [Internet]. 2012 [cited 2015 May 1]; Available from: http://www.theplantlist.org/

35. Stevens PF. Angiosperm Phylogeny Website [Internet]. 2012 [cited 2015 April 2]; Available from: http://www.mobot.org/MOBOT/ research/APweb/

36. Guarrera PM. Usi e tradizioni della flora italiana. Medicina popolare ed etnobotanica. Rome: Aracne; 2006.

37. Scherrer AM, Motti R, Weckerle CS. Traditional plant use in the 
areas of Monte Vesole and Ascea, Cilento National Park (Campania, Southern Italy). J Ethnopharmacol 2005;97:129-143. http://dx.doi. org/10.1016/j.jep.2004.11.002

38. Di Novella R, Di Novella N, de Martino L, Mancini L, de Feo V. Traditional plant use in the National Park of Cilento and Vallo di Diano. J Ethnopharmacol. 2013;145:328-342. http://dx.doi.org/10.1016/j. jep.2012.10.065

39. de Natale A, Pezzati GB, Pollio A. Extending the temporal context of ethnbotanical databases; the case study of the Campania region (southern Italy). J Ethnobiol Ethnomed. 2009;5:7. http://dx.doi. org/10.1186/1746-4269-5-7

40. Motti R, Antignani V, Idolo M. Traditional plant use in the Phlegrean Fields National Park (Campania, Southern Italy). Hum Ecol. 2009;37:775-782. http://dx.doi.org/10.1007/s10745-009-9254-1

41. Guarino C, de Simone L, Santoro S. Ethnobotanical study of the Sannio area, Campania, southern Italy. Ethnobotany Research and Applications. 2008;6:255-317.

42. Salerno G, Guarrera PM. Ricerche etnobotaniche nel Parco Nazionale del Cilento e Vallo di Diano: il territorio di Castel San Lorenzo (Campania, Salerno). Informatore Botanico Italiano. 2008;40:165-181.

43. Arcidiacono S, Pavone P, Sameri C. Le piante alimurgiche [Internet]. Le piante spontanee di uso alimentare nel Territorio Etneo. 2005 [cited 2015 Apr 1]; Available from: http://www.dipbot.unict.it/alimurgiche/ introduzione.htm

44. Lupia C. Etnobotanica. Le piante e i frutti spontanei della Sila Piccola catanzarese. Catanzaro: Abramo Editore; 2004.

45. Arcidiacono S, Costa R, Marletta G, Pavone P, Napoli M. Usi popolari delle piante selvatiche nel territorio di Villarosa (EN - Sicilia Centrale). Quaderni di Botanica Ambientale e Applicata. 2010;1:95-118.

46. Arcidiacono S, Napoli M, Oddo G, Pavone P. Piante selvatiche d'uso popolare nei territori di Alcara Li Fusi e Militello Rosamarino (Messina). Quaderni di Botanica Ambientale e Applicata. 2007;18:104-144.

47. Aleo M, Cambria S, Bazan G. Tradizioni etnofarmacobotaniche in alcune comunità rurali dei Monti di Trapani (Sicilia occidentale). Quaderni di Botanica Ambientale e Applicata. 2013;24:27-48.
48. Caneva G, Pontrandolfi MA, Fascetti S. Le piante alimentari spontanee della Basilicata. Potenza: Regione Basilicata; 1997.

49. Tartaglia M. L'uomo e le piante del Vulture. Milano: Franco Angeli; 2002.

50. Bianco VV, Mariani R, Santamaria P. Piante spontanee nella cucina tradizionale molese. Bari: Levante Editori; 2009.

51. Ditonno NM. Sapori e aromi da piante e frutti spontanei della Puglia peninsulare. Brindisi: Amici della A. De Leo; 1997.

52. Accogli R, Medagli P. Erbe spontanee salentine. Guida al riconoscimento e all'uso delle piante alimentari tradizionali. Lecce: Edizioni Grifo; 2014

53. Leporatti ML, Guarrera P. Ethnobotanical remarks in Capitanata and Salento areas (Puglia, southern Italy). Etnobiología. 2007;5:51-64.

54. Lupia C, Lupia R. Etnobotanica: piante e tradizioni popolari di Calabria. Viaggio alla scoperta di antichi saperi intorno al mondo delle piante. Crotone: Grafi.Co.; 2013.

55. Corrain C. Ricerche etnografiche nel Gargano. La cultura materiale. Rivista di Etnografia. 1962;1:63-98.

56. Pieroni A, Quave CL. Functional foods or food-medicines? On the consumption of wild plants among Albanians and southern Italians in Lucania. In: Pieroni A, Price LL, editors. Eating and healing: traditional food as medicine. Binghamton; Haworth Press; 2006. p. 101-129.

57. Guarrera PM, Savo V. Perceived health properties of wild and cultivated food plants in local and popular traditions of Italy: a review. J Ethnopharmacol. 2013;146:659-680. http://dx.doi.org/10.1016/j. jep.2013.01.036

58. Barthel S, Crumley CL, Svedin U. Biocultural refugia: combating the erosion of diversity in landscapes of food production. Ecol Soc. 2013;18:71. http://dx.doi.org/10.5751/ES-06207-180471

59. Biglino I, Olmo A, Pieroni A, Scaffidi C. Food policies and sustainability [Internet]. Bra: Slow Food / University of Gastronomic Sciences; 2011 [cited 2015 May 1]; Available from: https://www.slowfood.de/w/ files/slow_themen/food_policies_eng.pdf 